\title{
Does bank ownership affect relationship lending: A developing country perspective
}

\author{
Ashiqur Rahman \\ Department of Enterprise Economics, Tomas Bata University in Zlin \\ Czech Republic \\ rabman@fame.utb.cr. \\ Jaroslav Belas \\ Department of Enterprise Economics, Tomas Bata University in Zlin \\ Czech Republic \\ belas111@gmail.com

\section{Zoltan Rosza} \\ Department of Management, School of Economics and Management in \\ Public Administration in Bratislava \\ Slovak Republic \\ zoltan@rozsa.sk \\ Tomas Kliestik \\ University of Zilina \\ Slovak Republic \\ tomas.kliestik@fpedas.uniza.sk
}

Abstract. In this paper we aim to explore how the type of bank ownership - local private banks, government-owned banks (public banks) and foreign banks - can affect relationship lending to small and medium enterprises (SMEs) by using a unique data set from Bangladeshi banking sector. We found that private banks differ from government-owned and foreign banks in terms of relationship lending and credit facilities to SMEs. More specifically, our results suggest that unlike government and foreign banks, private banks do consider soft information from relationship lending while setting up the loan spread to SMEs. We can also confirm that exclusive banking relationship or repeated banking with private banks can soften credit conditions (loan maturity and covenants). Moreover, we found empirical evidence that banking relationship is important for private banks in terms of SME credit risk evaluation. Finally, as according to our expectation, the results confirm that regardless of prior relationship, private banks are more
Received: December, 2016 1st Revision: February, 2017 Accepted: April, 2017

DOI:

$10.14254 / 2071$ $8330.2017 / 10-1 / 20$ 
depended on collateral-based lending to SMEs than government-owned or foreign banks.

Keywords: bank financing, small and medium enterprises, bank ownership, relationship lending, Bangladesh.

JEL Classification: G21, L26, O16

\section{INTRODUCTION}

Contribution of Small and Medium Enterprises (SMEs) to the development of any economy is undeniable and, as a result, policy makers and researchers are actively involved in resolution of the issues faced by SMEs while ensuring their survival (Virglerova et al., 2016; Adamowicz, \& Machla, 2016; Dubravska et al., 2015; Spoz, 2014). Analysis of 76 developed and developing countries by Ayyagari et al. (2007) showed that SMEs are solely responsible for the creation of about 60 percent of employment in manufacturing sector. Moreover, SMEs also help improve socioeconomic conditions of a country by reducing import and producing products locally by fulfilling the needs of local community (Straka et al., 2015; Setyawan et al., 2015). Regardless of their significant contribution to the economy, the survival rate of SMEs is significantly lower than of large corporate firms due to various reasons, including restricted access to bank finance, high interest rates, lack of skilled labour forces, existence of technological and financial risks, severe competition from large firms etc. (Stafanovic et al., 2009; Norek \& Arenhardt, 2015; Kljucnikov et al., 2016).

It is widely contended that information opacity of SMEs is more severe than of larger firms, hence they need special banking assistance via relationship banking (Berger et al., 2001b). During the relationship with a bank customer banking information is gathered from the SME owner by a loan officer through repeated communication, also known as "soft information". This soft information is not easily transferable due to its nature and, as a result, it needs more judgmental analysis by the loan authority (Berger \& Udell, 2002). From the theoretical point of view, relationship banking can minimize information gap and facilitate SME's access to bank finance, because it is generally difficult to access proper audited financial data while lending to SMEs. Recent bank financing literature states that SMEs' access to bank financing can be affected by the ownership structure of banks, due to the fact that different banks have different organizational types and lending techniques. Therefore, soft information processing may not be suitable for all banks. Stein (2002) argues that banks with a simple and flat organizational structure can be in a better position to lend to SMEs as it is easier for them to transmit soft information which is necessary in small business lending. Similarly, flatter organizational structure of a bank gives more authority to bank officer which may allow them use more discretion in the loan decision-making process. More hierarchical structure of banks makes the process much more complicated, which may hamper the loan-decision process of banks. Research suggests that small and domestic private banks are more suitable for building a long-term relationship, they can process soft information more efficiently than other types of banks due to more simple organizational structure (Mian, 2006). Taking into consideration Stein (2002) arguments, it can be legitimate to argue that foreign banks are not in a superior position in SMEs' lending due to difficulties in access to local information. On the other hand, the research on government-owned banks suggests that they are more politically driven, and they act as the agents of political leaders in achieving their own goals (Sapienza, 2004). 
As a result, it is possible that government-owned banks may focus their support mainly on political party supporters, while other real business units may be left as credit rationed.

In this paper we examine the influence of banks' ownership types on SMEs financing, with the focus on possible differences in the relationship of private, government-owned and foreign banks to SMEs' lending. We also examine how the information from relationship lending can affect banks' decision in setting the interest rate, collateral, loan terms and credit risk management. To the best of our knowledge, this is the first research focused on the effect of bank ownership type to relationship lending and its outcome to SMEs in the context of Bangladesh. Our results indicate that significant differences between private, foreign and government-owned banks exist in terms of relationship lending and SME financing. The paper makes a significant contribution to understanding the importance of banking relationship for SMEs and how it may affect their financing possibilities in relation to different types of banks.

\section{LITERATURE REVIEW}

\subsection{Banks ownership and relationship lending}

Relationship lending, the most common techniques for lending to small firms, is based on the "soft" information which is accessible by keeping a close relationship with the client. Alternatively, there exist transaction-based lending techniques, those are mainly based on the "hard" information about the businesses. For example, financial statements based lending, asset based lending and credit scoring (Petersen \& Rajan, 2002). Researches dealing with the soft information generation and bank lending efficiency argue that the soft information collection and careful examination of the information can increase the lending efficiency of the bank that can positively affect the small business access to credit (D'Aurizio et al., 2015). On the other hand, empirical results show that commercial banks can improve the credit rating model by including the relationship lending qualitative (soft) information of the borrower in the rating process, and that focus only on the hard financial information can be misleading (Dolezal et al., 2015)

However, literature review shows that banking relationship and soft information generation can be affected by various factors including the type of bank ownership. It is found that information from the lending relationship are usually local in nature and, as a result, it is possible for the local banks to gather this proprietary information much better than for the distant banks (Jimenez et al., 2006). On the other hand, local domestic banks are better aware of the business condition in the community and hence they can evaluate the business prospects of the firm better than the foreign banks. Unfortunately for foreign banks, they have minimal local information and, as a consequence, have to rely mostly only on hard financial data for evaluating of SME loan application (Berger et al., 2001b).

La Porta et al. (2002) show that government-owned banks are dominating in the world economy. They found that in 1995 state-owned banks were holding about $42 \%$ of the asset in the banking industry around the globe. There exist several competing theories of government ownership of banks and its effect on bank lending. Literature shows that government-owned banks are established to fix the market failures and to drive the economy by which the government can implement its economic goals (Atkinson \& Stiglitz, 1980). On the other hand, Stiglitz (1993) argues that state-owned enterprises (SOEs) are there to improve the socio-economic conditions and by which they can improve the social welfare of the community. However, political view on state-owned enterprises suggests that politicians intentionally drive and implement policies through the SOEs to increase the benefit of their supporter (La Porta et al., 2002). Additionally, lack of incentives for the management in the state-owned banks demotivates them to spend more time and effort 
in a relationship lending (Berger et al., 2008). In contrast, private banks maintain better customer relationships, because of handsome incentives for bank managers, and also for the loan officers and therefore, they can process the soft information more efficiently (Beck et al., 2011). Therefore, depending on the bank ownership type, bank lending policies and techniques can differ and which is inherent in their organizational structure.

\subsection{Empirical evidence}

Researches of the influence of different types of bank's ownership on developing and emerging markets are quite limited. Results from the Indian market show that foreign banks are efficient in hard information based lending and as a result they prefer to lend to transparent firms that have audited financial statements (Gormley, 2006). Whereas, state-owned banks in India maintain a relationship based lending only to firms, to which they are instructed to assist by the government (Berger et al., 2008). In a crosscountry analysis (Argentina, Chile, Colombia, and Peru) Clarke et al. (2005) showed that large foreign banks lend to the small firms more than the large local private banks in Colombia and Chile. On the other hand, in Argentina and Chile, SME financing is showing a faster growth when foreign banks have significantly large share on the local market. Therefore, they argue that when a large foreign bank significantly deploys its resources on the local market it can penetrate it more than the host nation banks. Mian (2003) studied the bank lending behaviour in 100 emerging markets by surveying 1600 banks and stated that private banks are superior in the soft information based lending and hence, they can extend credits to SMEs more than foreign and government-owned banks.

In contrast, Nguyen \& Wolfee (2016) showed that government-owned banks in Vietnam provide more loans to SMEs than private banks, because government-owned banks have strong branch network, which helps them to build the relationship lending environment. They also find that bank-borrower exclusive relationship can increase the loan size and loan maturity. However, empirical results also show that it is possible to get loans with lower interest rates from the public banks as a result of political and hidden motives for lending to firms (Berger et al., 2008). Detragiache et al. (2006) in context of Malaysian market confirmed that foreign banks are lending only to well-established firms that have minimal default probabilities and hence foreign banks are using matching principle. That means that foreign banks only skim the cream and lend only to credit-worthy firms. Thus we can infer that large and transparent firms are more likely to benefit from the government-owned and foreign banks. Fiserova et al. (2015) in a cross country analysis showed that performance of the foreign banks in the host nation is not only affected by the bank own characteristics but also due to the economic condition of the host nation such as inflation rate and GDP growth.

In the context of Bangladesh, it is found that foreign banks ask for lower collateral and having collateral on a loan contract can increase access to finance (Rahman et al., 2016a, 2016b). Mian (2003) found that government-owned banks have less screening and monitoring processes for loans, and consequently, they require higher collateral. Likewise, government-owned banks have more predefined interest rates on the loans, which are higher than the rates of the private or foreign banks. Beck et al. (2011) found that foreign and large domestic public banks tend to provide loans with higher collateral and devote less attention to the soft relationship based information. Beck et al. (2011) concluded that large domestic and foreign banks use more arms-length lending, and so they ask for more collateral from the SMEs due to minimum access to the soft information. Nevertheless, private banks are superior in the soft information based lending and it may allow them to ask for more collateral from the SMEs to increase their superiority on the loan contract, as by nature relationship banking is risky. Moreover, some authors also suggest that small banks ask for 
more collateral from the SMEs than the large banks in emerging markets due to their capital shortages and also loan loss reduction incentives (Menkhoff et al., 2012). Taking this information into consideration we can also argue that the majority of the private banks in Bangladesh is small in comparison to the government-owned or foreign banks and, as a result, private banks can ask for more collateral from the SMEs than the government or foreign banks.

\subsection{Hypotheses}

In accordance with the aim of the paper we set four scientific hypotheses related with the type of bank ownership and its effect on various measures on relationship lending, including interest rate, collateral, loan terms and credit risk management of the SME loan.

H1. Private banks emphasize the relationship banking in setting up the interest rate more than the government-owned and foreign banks.

H2. Private banks can ask for higher collateral from the SMEs than the government-owned and foreign banks.

H3. An exclusive banking relationship with the private bank can relax the credit terms for SMEs (i.e. loan maturity and covenants).

H4. Private banks consider the relationship banking information for SME credit risk management more than the government-owned and foreign banks.

\section{DATA AND METHODOLOGY}

This study uses the data collected by a self-administered questionnaire survey during June, July and August 2015. Respondents were given five points Likert scale questions to disclose their opinion about relationship lending, on the scale ranging from 'strongly disagree' (1 point) to 'Strongly agree' (5 points) over the neutral point ( 3 points). Moreover, in line with the existing literature, we have recognized a relationship as a long-term one, when the length of the relationship between a bank and the borrower lasts for at least five years (Chang et al., 2014).

The survey was targeted on the bank credit officers who deal with SME finance. Our survey was purposively narrowed only of the SME credit officers, with the aim to tease out the most essential information that they consider while dealing with a loan proposal. The initial target of the survey was to collect data at least from one credit officer from all regular commercial banks that are operating in Bangladesh, including public (government-owned), private and foreign banks. ${ }^{1}$ We were able to collected data from 110 credit officers from 44 commercial banks, mainly from their different branches operating in Dhaka city - the capital of Bangladesh. Our data set is quite unique due to the fact that most of the survey was performed within the relationship lending area, where the data from SME owners or firm level are collected. Our data are directly from the SME credit officers, who can be considered as the main authority in a relationship banking that processes and transmits data to the upper authority for decision making. As a result, credit officers' opinion can be more valuable in a relationship lending than the SME owners may think.

${ }^{1}$ Currently there are 56 commercial banks operating in Bangladesh, where 8 banks are controlled and owned by the government, 39 private commercial banks and 9 foreign banks. 
The study uses descriptive statistics as a mean of gaining understanding about the banks characteristics. In addition, this study applied the test of Chi-square in order to examine the validity of hypotheses. For the purpose of the empirical analysis we decided to analyse private banks in comparison with the merged group of public and foreign banks, due to our persuasion of their similar characteristics as a result of their large organizational structure and hierarchical decision-making process. We have to state that data from both public and foreign banks are limited, as our data set covers only 10 responses from 5 foreign banks and 25 responses from 4 major public banks.

\subsection{Descriptive statistics}

Table 1 presents the summary statistics of our full data set of 44 banks as well as segmented analysis according to the bank ownership types (public, private and foreign). While considering the full data sample we can see that the mean Bank Age is 22 years, so represented banks are neither too old, nor very young. It is noticeable that on an average SME Advance to Total Advance Ratio is about 15 per cent. It means that commercial banks loan exposure in the SME segment in Bangladesh is not so high. At the same time, it is noticeable that about $73 \%$ of total advance is secured by fixed asset collateral in the form of land, machinery and vehicles. On the other hand, personal guaranty (29\%) and third-party guaranty (11\%) are also important mechanisms for secured lending to SMEs by commercial banks.

If we consider the segmented analysis across the bank ownership type, we see that state-owned banks are much bigger in terms of Total Assets and also older than the private and foreign banks. It suggests that government set up the state-owned banks to boost the economic development of the country in order to start a new economy right after gaining the independence of Bangladesh. With regards to SME Advance to Total Advance Ratio, private banks are outperforming public banks by $10 \%$ and foreign banks by $9 \%$. This indicates that private banks are recognizing the diversification of their portfolio to SMEs and similarly it can be possible that corporate lending market is getting more saturated. On contrary, the difference between public and foreign banks in terms of SME Advance to Total Advance Ratio is insignificant, which can be explained by the fact that public and foreign banks favour the corporate clients rather than the SME clients, because of the fact that corporate clients usually present higher level of information transparency due to obligatory audited financial statements as well as better market reputation. The result also suggest that both public and foreign banks are more concerned about collateral-based lending, as about $81 \%$ of the loans in the public banks and about $83 \%$ of the loans in the foreign banks segment are collateralized by fixed assets. Consequently, the financial data of the banks suggest that private banks are less concerned about mortgaged based lending while government and foreign banks are more comfortable in secured lending.

Total bank assets and all other secondary data used for our analyses are collected from the annual reports and audited financial statements of the banks that were published in 2014. Banks financial statements for the year 2015 have not yet been published. 
All banks $\mathrm{N}=44$; Public bank $\mathrm{N}=4$; Private bank $\mathrm{N}=35$; Foreign bank $\mathrm{N}=5$.

\begin{tabular}{|c|c|c|c|c|}
\hline & \multicolumn{4}{|c|}{ Bank Ownership Type } \\
\hline & All Banks & Public bank & Private bank & $\begin{array}{c}\text { Foreign } \\
\text { bank }\end{array}$ \\
\hline Variable/Bank characteristics & Mean & Mean & Mean & Mean \\
\hline Bank Age (years) & $22(12)$ & $43(.50)$ & $19(11)$ & $23(14)$ \\
\hline No. Of Total Branches & $180(270)$ & $944(290)$ & $114(75)$ & $17(10)$ \\
\hline No. Of Total Employees & $3175(4181)$ & $13489(7191)$ & $2324(1681)$ & $703(810)$ \\
\hline Total Assets (BDT Million)* & $182460(168508)$ & $581748(278514)$ & $149298(78973)$ & $88523(84559)$ \\
\hline Total Deposits (BDT Million)* & $144612(138860)$ & $475033(235255)$ & $118043(62719)$ & $60947(59916)$ \\
\hline Total Advances (BDT Million)* & $103310(75434)$ & $252402(98562)$ & $94711(51952)$ & $42507(45200)$ \\
\hline SME Advances (BDT Million)* & $15717(15864)$ & $21401(15646)$ & $16736(16171)$ & $4236(5503)$ \\
\hline $\begin{array}{l}\text { SME Advance To Total Advance } \\
\text { Ratio }\end{array}$ & $15(10)$ & $7(4)$ & $17(11)$ & $8(5)$ \\
\hline $\begin{array}{l}\text { Personal Guarantee (BDT } \\
\text { Million)* }\end{array}$ & 14991(19170) & $11842(4715)$ & $14251(17760)$ & $27575(35218)$ \\
\hline $\begin{array}{l}\text { Third party Guarantee (BDT } \\
\text { Million)* }\end{array}$ & $6483(7373)$ & $14118(8164)$ & $5569(6782)$ & $6286(6151)$ \\
\hline $\begin{array}{l}\text { Fixed Assets collateral to Total } \\
\text { Advance Ratio }\end{array}$ & 73 & 81 & 72 & 83 \\
\hline $\begin{array}{l}\text { Personal Guarantee to Total } \\
\text { Advance Ratio }\end{array}$ & 29 & 4.6 & 3 & 19 \\
\hline $\begin{array}{l}\text { Third party Guarantee to Total } \\
\text { Advance Ratio }\end{array}$ & 11 & 5.2 & 13 & 2 \\
\hline
\end{tabular}

Standard deviations are in parenthesizes.

Source: Bank's annual statements 2014; Authors' calculations

*1 USD $=77.87$ Bangladeshi Taka (BDT) as of 31 December 2014.

\section{EMPIRICAL RESULTS AND DISCUSSION}

Table 2

Test of Hypotheses

\begin{tabular}{|l|c|c|}
\hline \multirow{2}{*}{} & \multicolumn{2}{|c|}{ Bank Ownership Type } \\
\cline { 2 - 3 } & $\begin{array}{c}\text { Chi-Square } \\
\text { Value }\end{array}$ & P-Value \\
\hline H1: Relationship banking and lending interest rate & 8.203 & $\mathbf{0 . 0 8 4 *}$ \\
\hline H2: Borrowers without collateral are more likely to be credit rationed & 8.175 & $\mathbf{0 . 0 8 5 *}$ \\
\hline $\begin{array}{l}\text { H3: Exclusive bank-borrower relationship facilitates loan terms } \\
\text { (duration and covenants) }\end{array}$ & 10.171 & $\mathbf{0 . 0 3 8 ^ { * * }}$ \\
\hline H4: Relationship lending helps to minimize credit risk & 17.791 & $\mathbf{0 . 0 0 1 * * *}$ \\
\hline
\end{tabular}

Source: Authors' results. * indicates significance level at 0.10 level, ** indicates significance level at 0.05 level, *** indicates significance level at 0.01 level. 
Table 2 presents the results of the quantitative evaluation of our scientific hypotheses that was made in order to understand how relationship banking and the lending information are evaluated by private, public and foreign banks to process SME loans application. Furthermore, whether the soft information from lending relationship helps the bank to set the loan conditions and also to evaluate the credit risk of the loan. At first, we see that how private and other (public and foreign) banks treat the relationship banking soft information for setting the loan spread for SME borrowers. Our result is significant at $10 \%$ significance level. We found the evidence that private banks pay more attention to the relationship information for setting up the loan spread than public and foreign banks. Our result is consistent with the result of Beck et al. (2011), who stated that private banks are better able to manage a long-term customer relationship and hence can provide loans with lower interest rate. Therefore, we can accept our first hypothesis H1 and propose that private banks in Bangladesh do consider prior lending information while setting up the interest rates more intensively than government-owned or foreign banks do. According to the result we also propose that a long-term relationship with the private bank may help the SMEs to get access to bank loans with lower interest rates. Therefore, relationship banking is helpful for firms that are unable to provide audited financial statements, or firms those have problems to present their better credit quality. Our result can be influenced by the simple organizational structure of the private banks, or more incentives for the private bank loan officer to produce soft information for an efficient lending decision. In contrast, the large organizational structure of the public and foreign banks may allow them to focus more on the corporate clients rather than the SME clients. Similarly, it can also be the cause of heavy dependency of foreign and public banks on the hard financial information for processing SME credit (Berger et al., 2008). Our results are also consistent with the prior research and that foreign banks are less efficient in using the soft information (Clarke et al., 2005). Hence, we can say that soft information is more local in nature and it is not suitable for foreign banks to access the soft information due to the higher cost of collecting the soft information. At the same time, large organizational structure of public banks may impose barriers to using the soft information to evaluate the appropriate interest rate for a borrower.

We also hypothesized that whether SMEs are credit rationed from the private banks due to lower availability of collateral, their smaller size and focus more on risky relationship lending. We have found evidence that it is possible to be credit rationed from the private banks without collateral and our result is significant at 10\% significant level. Hypothesis $\mathrm{H} 2$ is confirmed. This result signifies that private banks do consider the soft information for extending credit to SMEs. However, borrowers are more likely to be credit rationed from the private banks as a result of lack of collateral. Empirical research show that large foreign banks use more arms-length lending, which reduces collateral requirements for SMEs (Jimenez et al., 2006). On the other hand, Menkhoff et al. (2012) confirmed that banks use collateral to secure their capital from the bad loans and hence, as private banks are smaller in size, as a result, they are more concerned about the reduction of any loan losses which may occur from loan defaults. On top of that, use of the soft information may not always correctly generate accurate credit risk level of the borrower because of the soft information interpretation errors and hence, banks use collateral to minimize moral hazard in SME lending (D'Aurizio et al., 2015). Berger et al. (2001a) find that use of small business credit scoring reduces credit rationing to a great extent in the context of USA. Thus, foreign and public banks' usage of credit scoring technology may facilitate the lending for SMEs more than from the private banks. We can summarise our results stating that private banks more intensively emphasize on collateral as a result of their size and capital constraints, since private banks neither benefit from the government guarantees like public banks, nor any support from the parent organization like the foreign banks. 
We researched whether the exclusive banking relationship with the private banks in comparison to public and foreign banks generates any benefit for the SMEs in terms of relaxed loan terms, for example, loan maturity and covenants. We have found that exclusive relationship in a form of usage of more products and services does provide benefits for the SMEs with the loan terms from the private banks. The result is valid at $5 \%$ significance level. Hence, we confirm that exclusive banking relationship is valued by private banks while dealing with the loan application and we consequently accept hypothesis $\mathrm{H} 3$. On the other hand, the results may be interpreted in a way that private banks do consider their loyal customer loan application with more sincerity and try to provide their best services. Nevertheless, as public and foreign banks have similar lending techniques (arms-length lending) as a result it may not generate any banking benefits for the SMEs. Public banks may provide extra benefits only to their politically involved customers and foreign banks can provide additional benefits to their corporate clients due to extensive investment to the corporate portfolio. However, Stein (2002) showed that exclusive banking adversely affects the loan terms for the SMEs as a result of rent seeking behaviour of the banks. Moreover, exclusive banking can increase the firm's switching costs and hence banks can charge higher interest rate and require higher collateral (Stein, 2002). The above-mentioned research did not examine the exclusive banking relationships with appropriate duration and covenants. Our research provide more evidence about the exclusive banking relationship and its effect on SME lending.

Finally, we examined whether bank ownership matters in case of evaluation of the soft information for credit risk management of the firms. Specially, whether private banks use the soft information more than public and foreign banks for determining the credit risk of the loan. We supposed that private banks will give more emphasize on the soft information for SME credit risk than other type banks. According to our result, we can confirm that private banks do evaluate soft information more closely than public and foreign banks for evaluating the credit risk of the loan. Hence, we can say that soft information generated from the banking relationship helps private commercial banks to evaluate the probability of defaults on the extended loan. Our result can be justified not exactly from bank ownership perspective as we do not have any prior research on the issue. Nevertheless, we can qualify our results from the soft information based lending perspective (Uchida et al., 2012). Results from the large banks standpoint suggest that they are not willing to use soft information for credit risk evaluation due to agency cost associated within the organization (Berger and Udell, 2002). Additionally, large banking structure of public and foreign banks make it difficult to use the soft information for credit risk evaluation. Consequently, we can infer that the soft information from banking relationship is helpful for the private banks in classifying the credit risk of the firm beyond the hard financial information based lending.

\section{CONCLUSION}

In this paper we aimed to explore how the type of bank ownership - local private banks, governmentowned banks (public banks) and foreign banks - can affect the relationship lending efficiency of banks, since, different banks have different organizational structure and lending techniques. We hypothesized that private banks will be more efficient in relationship banking than government-owned and foreign banks as a result of their expertise in soft information processing. As a consequence, private banks will consider the soft private information while setting up interest rates, loan maturity, collateral and credit risk of the SME borrower. We have used a new data set from Bangladesh which was collected from 44 commercial banks.

Empirical results of the paper show that private banks do value the soft information while setting up the interest spread in a loan contract for SMEs more than government-owned or foreign banks. Thus, we found confirmation that proprietary soft information provides additional benefits to the banks beyond the 
hard financial data. We tested the hypothesis whether the exclusive relationship between the bank and the borrower helps the firm to get loans with longer maturity with relaxed covenants. According to our expectation, we found that exclusive relationship with the private banks through repeated use of products and services helps the SME borrowers to receive loans with longer maturity and with relaxed covenants. Thus, we can infer that exclusive banking relationship can be helpful for borrowers from the private banks but not from the government or foreign banks to get loans with longer maturity and less strict loan terms. Furthermore, we confirm that relationship banking information is significantly considered by the private banks while rating the credit risk of the borrower. Therefore, the result shows the significance of the soft information in evaluating the credit risk for SMEs. Moreover, we also find empirical support that private banks emphasize more on collateral-based lending in comparison to public or foreign banks. Our result suggests that it is possible that potential borrowers are more likely to be credit rejected from the private banks when collateral is not pledged due to their small asset base. Private banks are smaller and they need to protect their loan portfolio from bad loans through secured lending. We conclude that private banks may have a comparative advantage in relationship lending over the government-owned or foreign banks. Since, private banks have a flatter organizational structure which gives them an advantage of information processing. Additionally, it is also possible that better structure of the incentives of the private bank managers or loan officers is motivating them to be more effective in relationship banking. On the other hand, government and foreign banks can be more efficient in arms-length lending as a result of their complex hierarchical organizational structure.

Despite of the significant contributions regarding the influence of bank ownership structure on the relationship lending, this paper has few drawbacks. At first, we did not differentiate between governmentowned and foreign banks due to data limitation. It is possible that these two types of the banks have different lending criteria and lending techniques. Moreover, our data set did not cover all the commercial banks those are active in SME lending in Bangladesh and we may leave out significant attributes from the left-out banks. Moreover, our results are based on the opinion of the credit officers and it may not reflect the actual situation in the banking industry. Finally, our data set is generated only from Dhaka - the capital city of Bangladesh. Therefore, we cannot generalize our result on other regions of Bangladesh where financial market is not so well developed. Therefore, we leave them for our future research scope.

\section{ACKNOWLEDGEMENT}

The authors are thankful to the Internal Grant Agency of FaME TBU No. IGA/FaME/2017/010: Financial Constraints on Economic Activities, for financial support to carry out this research.

\section{REFERENCES}

Adamowicz, M., \& Machla, A. (2016). Small and Medium Enterprises and the Support Policy of Local Government. Oeconomia Copernicana, 7(3), 405-437. doi: http://dx.doi.org/10.12775/OeC.2016.024

Atkinson, A.B., \& Stiglitz, J.E. (1980). Lectures on Public Economics. London, McGraw Hill.

Ayyagari, M., Beck, T., \& Demirguc-kunt, A. (2007). Small and medium enterprises across the globe. Small Business Economics, 29, 415-434. doi: http://dx.doi.org/10.1596/1813-9450-3127

Beck, T., Demirguc-Kunt, A., Martinez Peira, M.S. (2011). Bank financing for SMEs: evidence across countries and bank ownership types. Journal of Financial Services Research, 39, pp. 35-54. doi: 10.1007/s10693-010-0085-4

Berger, A.N., \& Udell, G.F. (2002). Small business credit availability and relationship lending: the importance of bank organizational structure. The Economic Journal, 112(477), 32-53. doi: 10.1111/1468-0297.00682 
Berger, A.N., Goldberg, L.G., \& White, L.J. (2001a). The effects of dynamic changes in bank competition on the supply of small business credit. European Financial Review, 5, 115-139.

Berger, A.N., Klapper, L.F., \& Udell, G.F. (2001b). The ability of banks to lend to informationally opaque small business. Journal of Banking and Finance, 25, 2127-2167. doi: 10.1016/S0378-4266(01)00189-3

Berger, A.N., Klapper, L.F., Martinez-Peria, M.S., \& Zaidi. R. (2008). Bank ownership and banking Relationships. Journal of Financial Intermediation, 17, 37-62. doi: 10.1016/j.jfi.2006.11.001

Chang, C., Liao, G., Yu, X., \& Ni, Z. (2014). Information from lending relationship: evidence from loan defaults in China. Journal of Money, Credit and Banking, 46(6), 1225-1257.

Clarke, G., Cull, R., Martinez Peria, M.S., Sanchez, S.M., (2005). Bank lending to small business in Latin America: Does bank origin matter? Journal of Banking Money, Credit, and Banking, 37, 83-118.

D’Aurizio, L., Oliveiro, T., \& Romano, L. (2015). Family firms, soft information and bank lending in a financial crisis. Journal of Corporate Finance, 33, 279-292. doi: http://dx.doi.org/10.1016/j.jcorpfin.2015.01.002

Detragiache, E., Tressel, T., \& Gupta, P. (2006). Foreign banks in poor countries: Theory and evidence. IMF Working Paper No. 18. International Monetary Fund, Washington DC.

Dolezal, J., Snajdr, J., Belas, J., Vincurova, Z. (2015). Model of the loan process in the context of unrealized income and loss prevention. Journal of International Studies, 8(1), 91-106. doi: 10.14254/2071-8330.2015/8-1/8

Dubravska, M., Mura, L., Kotulic, R., \& Novotny, J. (2015). Internationalization of Entrepreneurship-Motivating Factors: Case Study of the Slovak Republic. Acta Polytechnica Hungarica, 12(5), 121-133.

Fiserova, T., Teply, P., \& Tripe, D. (2015). The performance of foreign-owned banks in the host country economics. Prague Economic Papers, 24(5), 1-24. doi: 10.18267/j.pep.527

Gormley, S., Kanatas., G., \& Venezia, I. (2006). Bank competition in developing countries: does foreign bank entry improve credit access? Mimeo. MIT.

Jimenez, G., Salas, V., Saurina, J. (2006). Determinants of collateral. Journal of Financial Economics, 81, 255-281. doi: 10.1016/j.jfineco.2005.06.003

Kljucnikov A., Belas, J., Kozubikova, L., \& Pasekova P. (2016).The Entrepreneurial Perception of SME Business Environment Quality in the Czech Republic. Journal of Competitiveness, 8(1), 66-78.

La Porta, R., Lopez-de-Silances, F., \& Shleifer, A. (2002). Government ownership of commercial banks. Journal of Finance, 57(1), 265-301. doi: 10.1111/1540-6261.00422

Menkhoff, L., Neuberger, D., \& Rungruxsirivorn, O. (2012). Collateral and its substitutes in emerging markets lending. Journal of Banking and Finance, 36, 817-834.

Mian, A. (2003). Foreign, private domestic, and government banks: New evidence from emerging markets. University of Chicago, Mimeo.

Mian, A. (2006). Distance constraints: the limits of foreign lending in poor economics. Journal of Finance, 61(3), 14651505. doi: 10.1111/j.1540-6261.2006.00878.x

Nguyen, S., \& Wolfee, S. (2016). Determinants of successful access to bank loans by Vietnamese SMEs: new evidence from the red river delta. Journal of Internet Banking and Commerce, 21(1), 1-23.

Norek, T., \& Arenhardt, D. L. (2015). Comparative analysis of innovative activity determinants in selected SMEs in Brazil and Poland. Results of empirical researches. EQUILIBRIUM. Quarterly Journal of Economics and Economic Policy, 10(2), 157-181. doi: http://dx.doi.org/10.12775/EQUIL.2015.018

Petersen, M.A., \& Rajan, R.G. (2002). Does distance still matter? The information revolution in small business lending. The Journal of Finance, 57, 2533-2570. DOI: 10.1111/1540-6261.00505

Rahman, A., Rahman, M.T., \& Kljucnikov, A. (2016a). Collateral and SME Financing: An Analysis Across Bank Size and Bank Ownership Types. Journal of International Studies, 9(2), 112-126.

Rahman, A., Rahman, M.T., \& Kljucnikov, A. (2016b). Bank Size, Relationship Lending and SME Financing: Evidence from Bangladesh. Actual Problems of Economics, 183, 294-307.

Sapienza, P. (2004). The effects of government ownership on bank lending. Journal of Financial Economics, $72(2), 357-$ 384. doi: 10.1016/j.jfineco.2002.10.002

Setyawan, A.A., Isa, M., Wajdi, F.M., Symsudin., \& Nugroho, P.S. (2015). An assessment of SME competitiveness in Indonesia. Journal of Competitiveness, 7(2), 60-74. doi: 10.7441/joc.2015.02.04 
Spoz, A. (2014). Significance of the EU Funds in Investments of Small and Medium-Sized Enterprises. Oeconomia Copernicana, 5(4), 61-74. doi: http://dx.doi.org/10.12775/OeC.2014.027

Stefanovic, I., Milosevic, D., \& Miletic, S. (2009). Significance and development problems of SMEs in contemporary market economy. Serbian Journal of Management, 4(1), 127-136.

Stein, J. (2002). Information production and capital allocation: decentralized vs. hierarchical firms. Journal of Finance, 57, 1891-1921. doi: 10.1111/0022-1082.00483

Stiglitz, J.E. (1993). The role of state in financial markets. Proceedings of the World Bank Annual Conference on Economic Development, Washington DC, International Bank for Reconstruction and Development, World Bank, 19-56.

Straka, J., Birciakova, N., \& Stavkova, J. (2015). Impact of SMEs on standard of living on Czech rural households. Economics and Sociology, 8(4), 51-64. doi: 10.14254/2071-789X.2015/8-4/4

Uchida, H., Udell, G.F., \& Yamori, N. (2012). Loan officers and relationship lending to SMEs. Journal of Financial Intermediation, 21, 97-122. doi: 10.1016/j.jfi.2011.06.002

Virglerova, Z., Dobes, K, \& Vojtovic, S. (2016). The Perception of the State's Influence on its Business Environment in the Small and Medium Size Enterprise segment in the Czech Republic. Administration and Public Management Review, 26, 78-96. 